\title{
PHYLOGEOGRAPHIC AND GENETIC DIVERSITY OF PORCELLIONIDES PRUINOSUS AND PORCELLIO LAEVIS BY USING THE MITOCHONDRIAL CYTOCHROME C OXIDASE SUBUNIT 1 SEQUENCE
}

\author{
Mohammad Allam $^{1 *}$; Heba M. Fangary ${ }^{1}$; Zeinab A. Mar'ie ${ }^{1,2}$ \\ ${ }^{1}$ Zoology Department, Faculty of Science, South Valley University, Qena, Egypt \\ ${ }^{2}$ Science Department, Faculty of Education, South Valley University, Hurghada, Red Sea, \\ Egypt
}

\author{
Article History: \\ Received: 17 May 2021 \\ Revised: 16 June 2021 \\ Accepted: 27 June 2021 \\ Published Online: \\ 11 July 2021 \\ Keywords: \\ Genetic diversity \\ CO1 \\ Phylogeographic population \\ Porcellio laevis \\ Porcellionides pruinosus \\ *Correspondence: \\ Mohammad Allam \\ Zoology Department \\ Faculty of Science \\ South Valley University \\ Qena, Egypt \\ E-mail: \\ Mohammad_allam10@sci. \\ svu.edu.eg
}

\begin{abstract}
Among Oniscidea suborder, Porcellionidae is the richest and widely-distributed Family. However, the phylogeny investigations of its taxa were not completely covered. Therefore, a phylogeographic population and genetic diversity study was carried out here on two cosmopolitan terrestrial isopod species (Porcellionides pruinosus and Porcellio laevis) by utilizing mitochondrial cytochrome c oxidase subunit 1 (CO1) gene. The sequencing of CO1 among the understudied populations showed nucleotide length ranged from 646 base pairs (bp) to $660 \mathrm{bp}$. The average contents of nucleotide bases $\mathrm{A}+\mathrm{T}$ in Porcellionides pruinosus and Porcellio laevis were $63.8 \%$ and $63.3 \%$, respectively. Also, the average content of pyrimidines $(\mathrm{C}+\mathrm{T})$ bases in Porcellionides pruinosus and Porcellio laevis was higher than the purines content. Nucleotide bases $\mathrm{A}+\mathrm{T}$ contents were higher than nucleotide bases $\mathrm{C}+\mathrm{G}$ contents in all populations. The pairwise genetic distances among the understudied Porcellionides pruinosus populations ranged from 0.000 to 0.002 . The most related populations were in Qeft and Deshna, where the genetic distance was 0.000 . The pairwise genetic distances among the understudied populations of Porcellio laevis ranged from 0.017 to 0.033. The most related populations were in Qeft and Hurghada, where the genetic distance was 0.017 . Furthermore, Porcellio laevis populations need more investigations, as it seems to be polyphyletic comparing to Porcellionides pruinosus populations.
\end{abstract}

\section{INTRODUCTION}

Terrestrial isopods are essential representatives of soil fauna. They have a significant role in mineralizing organic matter, as well as in decomposing leaf litter ${ }^{[1-3]}$. Generally, terrestrial isopod systematics is complicated and controversial ${ }^{[4]}$. The Oniscidea is greatly distributed, with the exception of Antarctica, it is found on every continent. Oniscidea is a varied suborder of the terrestrial isopods included more than 4000 species $^{[5]}$. However, due to they have low spread rates, need moist microhabitats, and brood their young in a pouch, they are expected to have 
limited gene flow within and among populations ${ }^{[6,7]}$. The spread of different isopod species was related to available habitats and habitat features at an accurate spatial scale, although some species may display different responses to environmental heterogeneity, which reflects a big interspecific diversity within the group ${ }^{[8]}$. The family "Porcellionidae" is one of the richest family in suborder Oniscidea, it has about 19 genera included 333 species $^{[9]}$. Porcellionidae were highly acclimated to terrestrial environments and can be occurred in a wide scale of habitats, from tropical rainforests to deserts. They were originally reported from the circum-Mediterranean region, Atlantic islands, Arabian Peninsula, and East Africa. For the time being, they found over the world ${ }^{[10,11]}$.

According to Schmalfuss ${ }^{[5]}$, both Porcellionides pruinosus (Brandt, 1833) and Porcellio laevis (Latreille, 1804) are belong to Porcellionidae family. Porcellionides pruinosus is an extremely spread species of terrestrial isopods, and it is a cosmopolitan woodlouse ${ }^{[12-13]}$. The systematic status of $P$. pruinosus is still confused and remains inconspicuous ${ }^{[14]}$. Porcellio laevis is a large and distinctive woodlouse. It is a cosmopolitan species, dispersal greatly over the world, including Western Asia, Japan, North and South America, Australia, and some Pacific islands, resulting in a complex synonymy $^{[5]}$.

Lee et $a .^{[15]}$ reported that great genetic variation has been found with an absence of apparent morphological divergence in at least some of the terrestrial isopods that have been studied $^{[13,16-18]}$. This increases the potential that they represent complex species. The assessment of the genetic variation of a species is an important gauge for its preservation, maintenance, and further genetic improvement ${ }^{[19]}$. The population genetic structure is due to many factors like ecological and geographical, which may lead to divergence and division of the populations. Moreover, gene flow, genetic drift, and the equilibrium between them can also lead to population genetic structure $^{[20,21]}$.

The mitochondrial genome has been used in wide scale in evolutionary and population genetics studies, by virtue of the high number of copies inside the cell, the ease of isolating it from the nuclear genome, and the small size and rapid accumulation of mutations ${ }^{[22-24]}$. Mitochondrial DNA has several features as introns lack, restricted recombination, has uniparental inheritance (mainly in animal phyla), and rise evolutionary rate ${ }^{[25,26]}$. The mitochondrial cytochrome $\mathrm{c}$ oxidase subunit 1 (CO1) protein-coding gene has been used in a wide scale as a practical and standardized species-level barcode for the majority of the animal kingdom ${ }^{[27]}$. The evolution rate of mitochondrial DNA and its amino acid sequence is very conserved to COI gene across the phyla and becomes very popular in various molecular tools in many genetic investigations $^{[28]}$.

Although the Porcellionidae family is considered among the richest families of Oniscidea, the phylogeny investigations of its taxa were not completely examined ${ }^{[29]}$. Thus, the objective of this study was to estimate the phylogeographic population and genetic diversity of two widely distributed species of family Porcellionidae (Porcellionides pruinosus and Porcellio laevis) using the CO1 gene.

\section{MATERIAL AND METHODS Sampling}

Specimens were collected between October 2019 and March 2020 from four localities from Egypt (Qeft, Qena, Deshna, and Hurghada), belonging to Qena and The Red Sea Governorates (Table 1). The two isopod species were identified as described previously ${ }^{[30]}$. The specimens were stored at $-20^{\circ} \mathrm{C}$ until used for genomic DNA extraction.

\section{DNA extraction}

The genomic DNA was extracted from the preserved leg tissues using the DNA 
extraction method of QIAamp DNA Mini kit (Qiagen, Hidden, Germany) by following the manufacturer's guidelines.

\section{Polymerase chain reaction (PCR) conditions}

Mitochondrial COI gene was amplified using the primers LCO1490 and HCO $2198^{[31]}$. The PCR reactions comprised of $10 \mathrm{pmol}$ of each forward and reverse primers, $20 \mu \mathrm{L}$ PCR master mix (OnePCR $^{\mathrm{TM}}$ ready-to-use, Catalogue Number: MB203-0100, GeneDireX, Miaoli County, Taiwan), and 50-90 ng of genomic DNA in a final reaction volume of $40 \mu \mathrm{L}$. The PCR program was performed with (a) an initial denaturation at $94^{\circ} \mathrm{C}$ for 180 seconds; (b) 35 cycles including denaturation, annealing, and an extension for 60 seconds at $94^{\circ} \mathrm{C}, 60$ seconds at $50^{\circ} \mathrm{C}$, and 60 seconds at $72^{\circ} \mathrm{C}$, respectively; (c) a final extension at $72^{\circ} \mathrm{C}$ for 7 minutes $^{[31]}$. Agarose gel $(1.5 \%)$ contained ethidium bromide was used to separate the amplified products; 100bp DNA Ladder ready-to-use (Catalogue Number:
DM001-R500, GeneDireX) was used as a DNA marker.

\section{The Sequencing of PCR}

All DNA sequencing was achieved by Macrogen (Seoul, South Korea) using the same primer used for amplification. The sequences were submitted to the National Center for Biotechnology Information (GenBank/NCBI) for obtaining accession numbers. The generated sequences were compared to NCBI COI sequences of Porcellionides pruinosus and Porcellio laevis and revealed $99-100 \%$ identity. Sequence alignment was performed using MUSCLE $^{[32]}$ with default settings. The nucleotide frequencies, AT and CG contents, as well as the phylogenetic trees analyses were performed with MEGA version $7.018^{[33]}$, using maximum likelihood (ML), neighbor joining (NJ), and minimum evolution (ME) methods of trees construction, as well as using 1000 bootstrap iterations ${ }^{[34]}$. Calculation of sequence divergences was occurred by utilize Kimura twoparameter distances $^{[35]}$.

Table 1: Localities and number of individuals of Porcellionides pruinosus and Porcellio laevis.

\begin{tabular}{llcccc}
\hline \multirow{2}{*}{ Governorate } & \multirow{2}{*}{ City } & \multicolumn{2}{c}{ Number of Individuals } & \multicolumn{2}{c}{ Geographic Locations } \\
\cline { 3 - 6 } & & Porcellionides pruinosus & Porcellio laevis & Latitudes & Longitudes \\
\hline Qena & Qena & 20 & - & $26^{\circ} 09^{\prime} 15.48^{\prime \prime} \mathrm{N}$ & $32^{\circ} 42^{\prime} 38.25^{\prime \prime} \mathrm{E}$ \\
Qena & Qeft & 30 & 50 & $25^{\circ} 59^{\prime} 52.50^{\prime \prime} \mathrm{N}$ & $32^{\circ} 48^{\prime} 59.89^{\prime \prime} \mathrm{E}$ \\
Qena & Deshna & 20 & 30 & $26^{\circ} 07^{\prime} 17.03^{\prime \prime} \mathrm{N}$ & $32^{\circ} 28^{\prime} 06.85^{\prime \prime} \mathrm{E}$ \\
The Red Sea & Hurghada & - & 20 & $27^{\circ} 15^{\prime} 28.83^{\prime \prime} \mathrm{N}$ & $32^{\circ} 48^{\prime} 41.90^{\prime \prime} \mathrm{E}$ \\
\hline
\end{tabular}

\section{RESULTS}

\section{Porcellionides pruinosus populations}

The sequencing of mitochondrial CO1 gene in the three populations of Porcellionides pruinosus produced nucleotide length ranged from 659 base pairs (bp) to $660 \mathrm{bp}$. The partial nucleotide sequences of CO1 were deposited in the GenBank under accession numbers (MW449532-MW449534). The average nucleotide frequencies of adenine $(A)$, cytosine $(C)$, guanine $(G)$, and thymine (T) were 24.3, 14.8, 21.4, and 39.5\%, respectively. The average $\mathrm{A}+\mathrm{T}$ content was $63.8 \%$, which was higher than the $\mathrm{C}+\mathrm{G}$ content. Also, the average content of pyrimidines $(\mathrm{C}+\mathrm{T})$ bases was 54.3 , which was higher than the purines content. More details about nucleotide frequencies, $\mathrm{A}+\mathrm{T}$ contents, pyrimidines contents, and their averages were given in (Table 2). The final alignments consisted of $660 \mathrm{bp}$; out of them 658,1 , and 1 were conserved sites, variable sites, and parsimony informative sites, respectively (Figure 1). 
Table 2: Accession number and nucleotide frequencies and their averages of mitochondrial cytochrome c oxidase subunit 1 (CO1) gene in three populations of Porcellionides pruinosus.

\begin{tabular}{|c|c|c|c|c|c|c|c|c|}
\hline \multirow{2}{*}{ Population } & \multirow{2}{*}{$\begin{array}{l}\text { Accession } \\
\text { Number }\end{array}$} & \multirow{2}{*}{$\begin{array}{l}\text { Base Pair } \\
\text { Length }\end{array}$} & \multicolumn{4}{|c|}{ Nucleotide (\%) } & \multirow{2}{*}{$\begin{array}{c}\mathrm{A}+\mathrm{T} \\
\text { Content }(\%)\end{array}$} & \multirow{2}{*}{$\begin{array}{c}\text { Pyrimidines }(\mathrm{C}+\mathrm{T}) \\
\text { Content }(\%)\end{array}$} \\
\hline & & & A & $\mathrm{T}$ & $\mathrm{C}$ & G & & \\
\hline Qeft & MW449532.1 & 659 & 24.3 & 39.5 & 14.8 & 21.4 & 63.8 & 54.3 \\
\hline Qena & MW449533.1 & 660 & 24.2 & 39.7 & 14.7 & 21.4 & 63.9 & 54.4 \\
\hline Deshna & MW449534.1 & 659 & 24.3 & 39.5 & 14.8 & 21.4 & 63.8 & 54.3 \\
\hline Average (\%) & - & & 24.3 & 39.5 & 14.8 & 21.4 & 63.8 & 54.3 \\
\hline
\end{tabular}

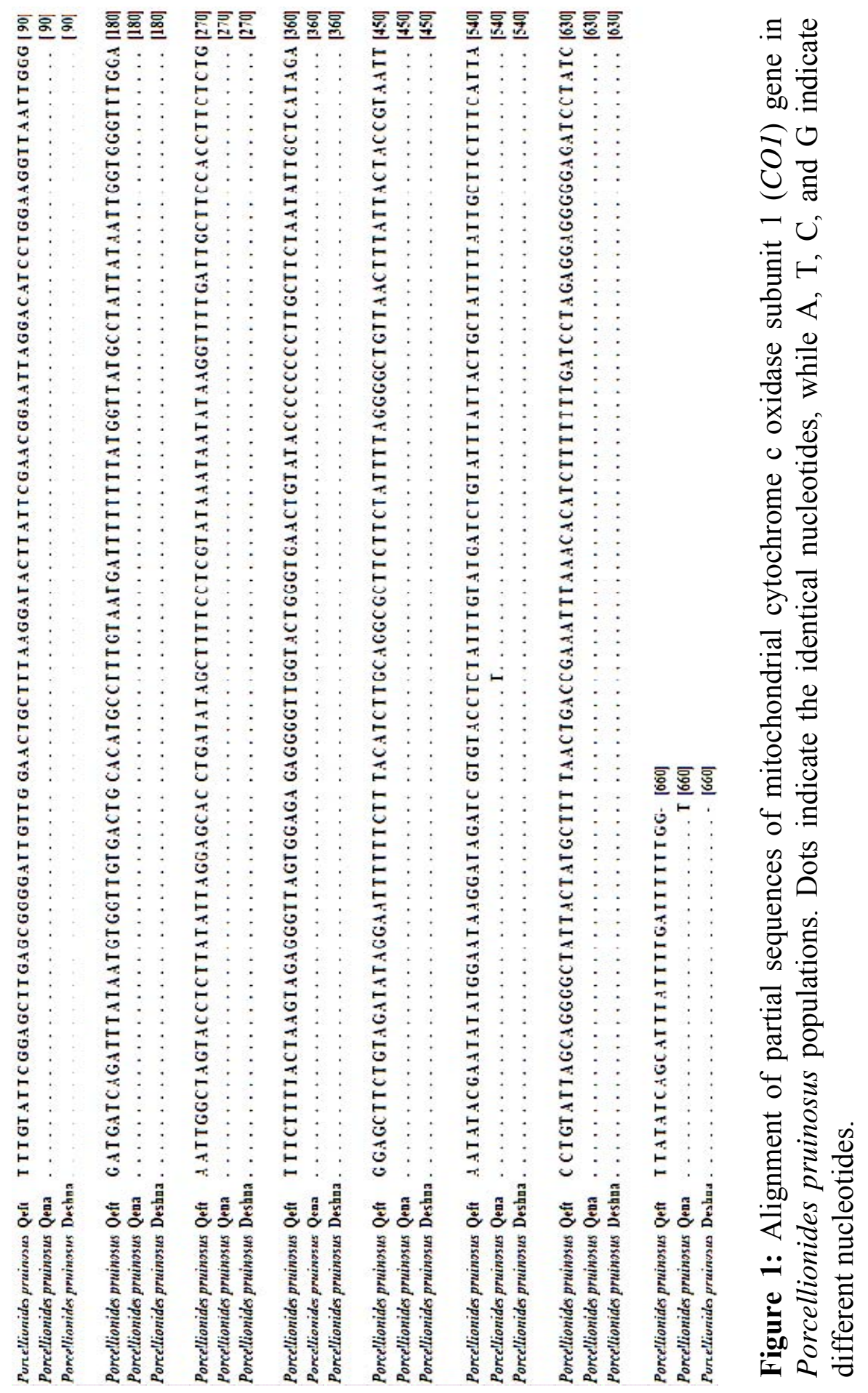


The sequences of CO1 in the three populations of Porcellionides pruinosus were subjected to BLAST/N at (NCBI) and revealed 12 related species from order Isopoda; representing six species (Porcellionides pruinosus, Porcellionides myrmecophilus, Porcellionidae sp., Porcellio scaber, Porcellio spinicornis, and Porcellio sp.) of family Porcellionidae, three species (Haloniscus longiantennatus, Haloniscus Searle, and Haloniscus sp.) of family Scyphacidae and one species (Armadillidium nasatum, Ligia dilatata, and Thysanoessa raschii) from each of the families Armadillidiidae, Ligia, and Euphausiidae, respectively; in addition to the out-group species (Orchomenella cavimanus, Orchomenella obtuse, and Orchomenella rotundifrons) of family Lysianassidae, order Amphipoda (Table 3). Among all the 12 related isopod species, the close genetic species to the understudied populations was Porcellionides pruinosus (KR424606.1), then Porcellionidae sp. (HM385141.1), while Haloniscus searlei (EU364621.1) was the most distantly species.

Table 3: The understudied Porcellionides pruinosus and Porcellio laevis populations with their related Oniscidea species, in addition to the out-group species from the GenBank/NCBI based on mitochondrial cytochrome c oxidase subunit 1 (CO1) genes sequences.

\begin{tabular}{|c|c|c|c|}
\hline Species & $\begin{array}{l}\text { Accession } \\
\text { Number }\end{array}$ & Species & $\begin{array}{l}\text { Accession } \\
\text { Number }\end{array}$ \\
\hline Porcellionides pruinosus, Qeft & MW449532.1 & Porcellio laevis, Deshna & MW449535.1 \\
\hline Porcellionides pruinosus, Qena & MW449533.1 & Porcellio laevi, Qeft & MW449536.1 \\
\hline Porcellionides pruinosus, Deshna & MW449534.1 & Porcellio laevis, Hurghada & MW449537.1 \\
\hline Porcellionides pruinosus & KR424606.1 & Porcellio laevis & HM385125.1 \\
\hline Porcellionidae sp. & HM385141.1 & Porcellio imbutus & FN824125.1 \\
\hline Haloniscus longiantennatus & EU364578.1 & Porcellio sp. & MH279740.1 \\
\hline Haloniscus sp. & KT236011.1 & Porcellionidae sp. & HM385141.1 \\
\hline Porcellionides myrmecophilus & FN824129.1 & Idotea resecata & JX545468.1 \\
\hline Thysanoessa raschii & KP241406.1 & Idotea urotoma & KU530527.1 \\
\hline Porcellio spinicornis & MG316309.1 & Idoteidae sp. & MH242805.1 \\
\hline Porcellio sp. & МH279740.1 & Synisoma capito & FJ905097.1 \\
\hline Armadillidium nasatum & FN824097.1 & Mongoloniscus sinensis & KT424028.1 \\
\hline Ligia dilatata & MH173101.1 & Mongoloniscus koreanus & LC017825.1 \\
\hline Porcellio scaber & MF750666.1 & Trachelipus rathkii & MK852336.1 \\
\hline Haloniscus searlei & EU364621.1 & Trachelipus kytherensis & EF027399.1 \\
\hline Out-group & & Halophiloscia couchii & KJ668172.1 \\
\hline Orchomenella franklini & HM054022.1 & Halophiloscia hirsuta & KJ668163.1 \\
\hline Orchomenella obtusa & MG935152.1 & Haloniscus longiantennatus & EU364584.1 \\
\hline \multirow[t]{9}{*}{ Orchomenella minuta } & MG319744.1 & Haloniscus sp. & EU364586.1 \\
\hline & & Amphisopus lintoni & JX519295.1 \\
\hline & & Ligia perkinsi & AY051336.1 \\
\hline & & Sphaeromatidae sp. & KY263277.1 \\
\hline & & Tylos sp. & KF007669.1 \\
\hline & & Out-group & \\
\hline & & Orchomenella obtusa & MG935152.1 \\
\hline & & Orchomenella cavimanus & GU109257.1 \\
\hline & & Orchomenella rotundifronss & MF124141.1 \\
\hline
\end{tabular}

Among the understudied Porcellionides pruinosus populations pairwise genetic distances ranged from 0.000 to 0.002 . The most related populations were in Qeft and 
Deshna, where the genetic distance was 0.000. Pairwise genetic distances among the understudied populations and other related

species of order Isopoda ranged from 0.000 to 0.041 . Overall, the mean distance value was $0.248 \%$ (Table 4 ).

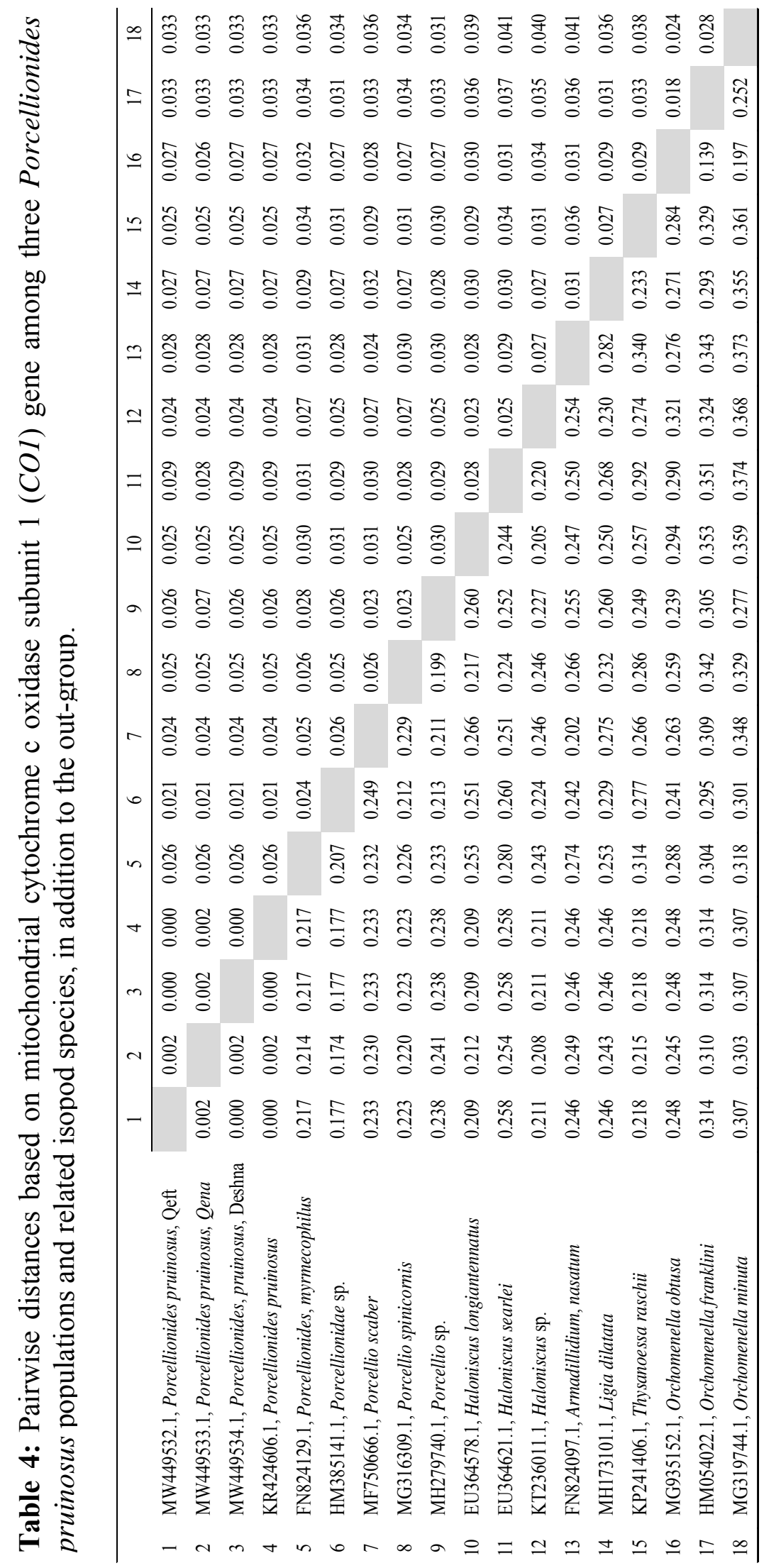


To carry out the phylogenetic tree analysis using CO1 sequencing, the three Porcellionides pruinosus populations were submitted to the analysis together with the 12 related isopod species sequences and the out-group species from GenBank/NCBI (previously mentioned in Table 4). For more illustrative phylogenetic relations, we used more than one phylogenetic method (ML, $\mathrm{NJ}$, and ME) based on CO1 gene. The methods showed nearly the same relations with some differences in support values and revealed 4 main features: (1) Species of outgroup formed a separate cluster. (2) The understudied Porcellionides pruinosus populations with Porcellionides pruinosus (KR424606.1) formed one main clade. (3) Both Porcellionides pruinosus populations of Deshna and Qeft formed a sister clade with Porcellionides pruinosus (KR424606.1). (4) Porcellionides pruinosus population of Qena formed a basal clade with the rest of Porcellionides pruinosus populations (Figures 2-4).

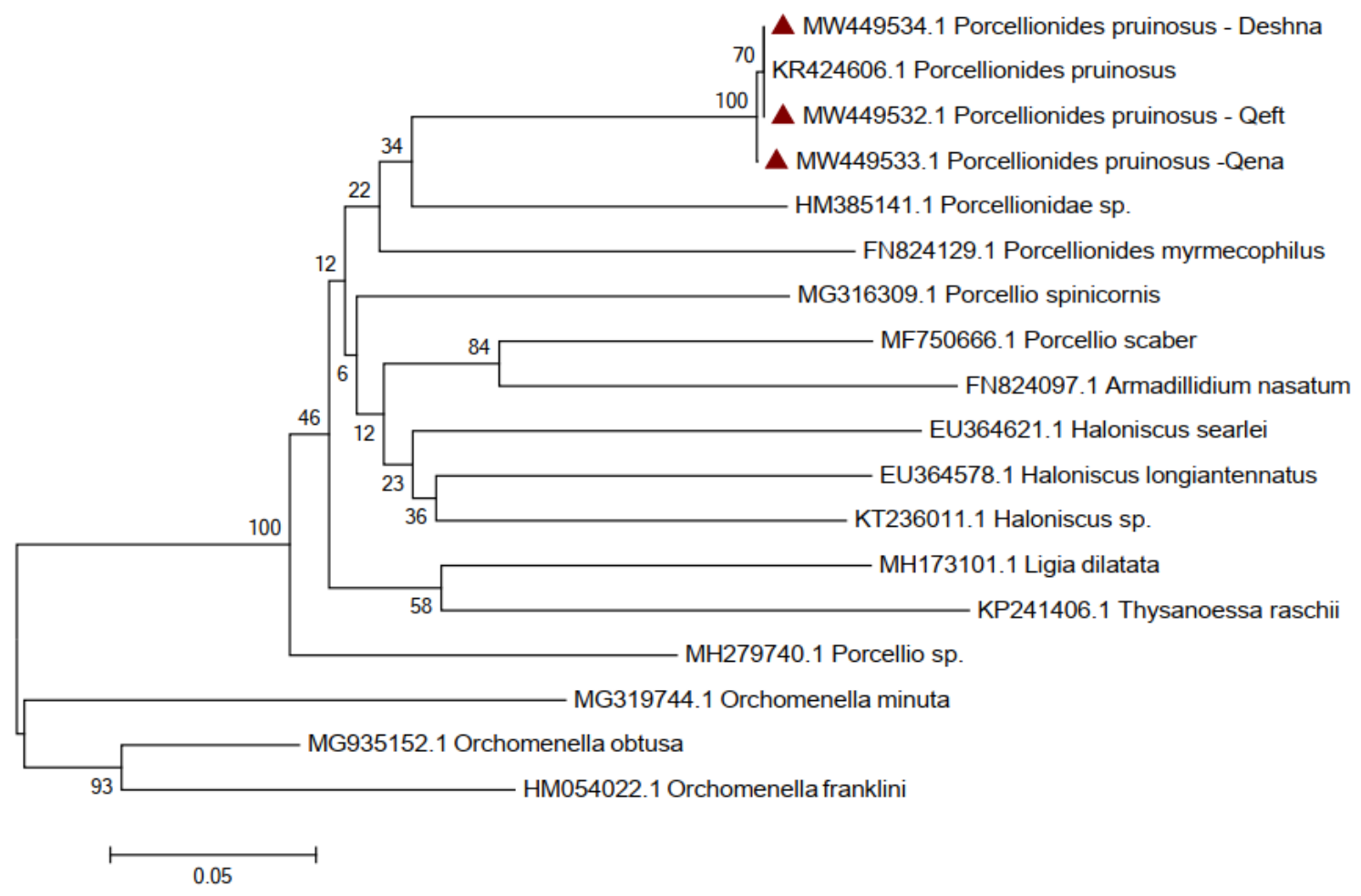

Figure 2: Phylogenetic tree using the maximum likelihood method among three Porcellionides pruinosus populations based on mitochondrial cytochrome oxidase subunit 1 (CO1) gene.

\section{Porcellio laevis populations}

The sequencing of CO1 gene in the three Porcellio laevis populations produced nucleotide length ranged from $646 \mathrm{bp}$ to $660 \mathrm{bp}$. The partial nucleotide sequences of CO1 were submitted in the GenBank with the accession numbers (MW449535MW449537). The results indicated that Deshna population has the shortest nucleotide sequences (646 bp). The average nucleotide frequencies of $\mathrm{A}, \mathrm{C}, \mathrm{G}$, and $\mathrm{T}$ were $25.7,15.8,20.9$, and $37.6 \%$, respectively. The average $\mathrm{A}+\mathrm{T}$ content was $63.3 \%$, which was higher than the $\mathrm{C}+\mathrm{G}$ content. Also, the average content of pyrimidines $(\mathrm{C}+\mathrm{T})$ bases was 53.4 , which was higher than the purines content. More details about nucleotide frequencies, $\mathrm{A}+\mathrm{T}$ contents, pyrimidines contents, and their averages were given in (Table 5). The final alignments consisted of $660 \mathrm{bp}$; out of them 497, 152, and 1 were conserved sites, variable sites, and Parsimony informative sites, respectively (Figure 5). 


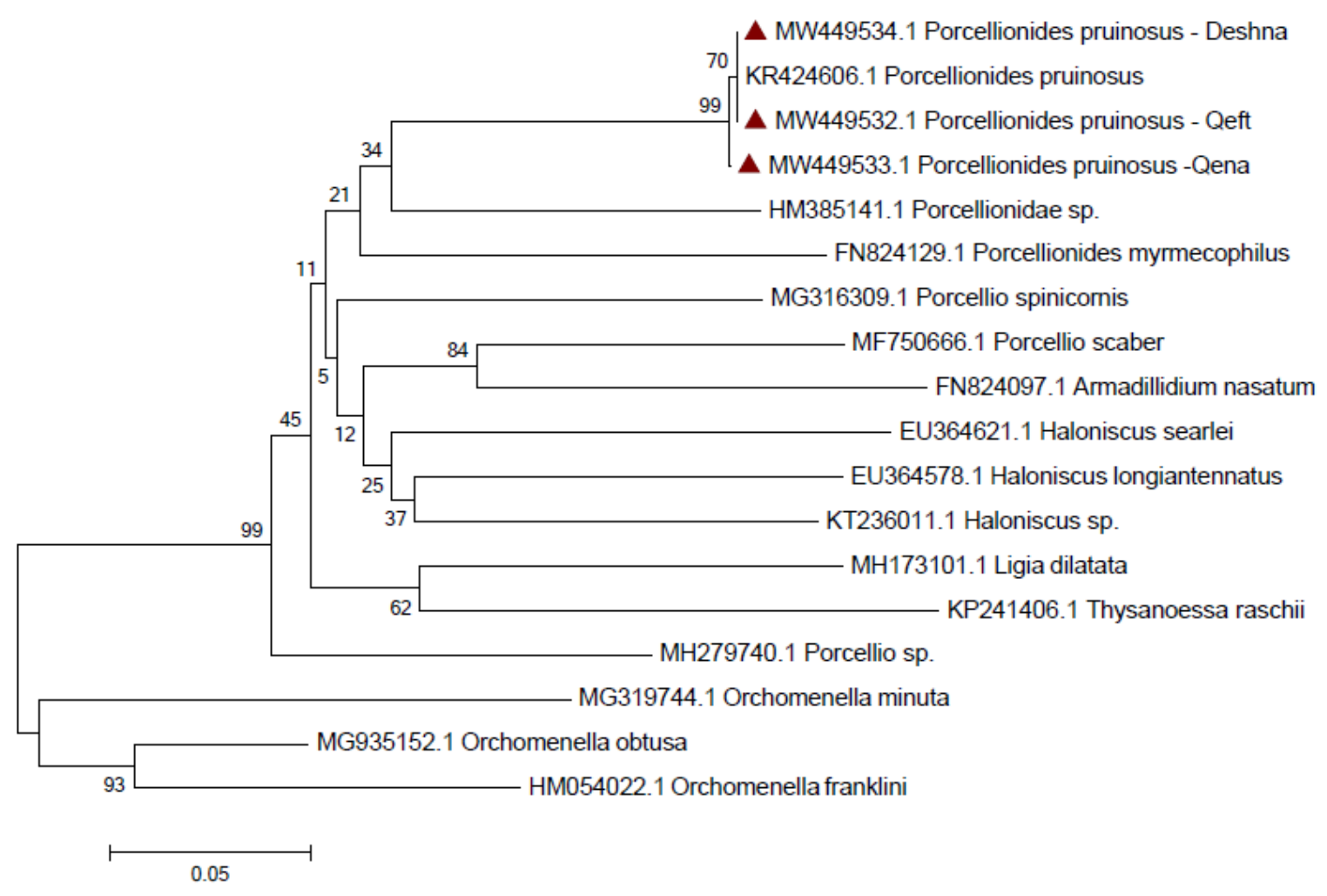

Figure 3: Phylogenetic tree using the neighbor joining method among three Porcellionides pruinosus populations based on mitochondrial cytochrome oxidase subunit 1 (CO1) gene.

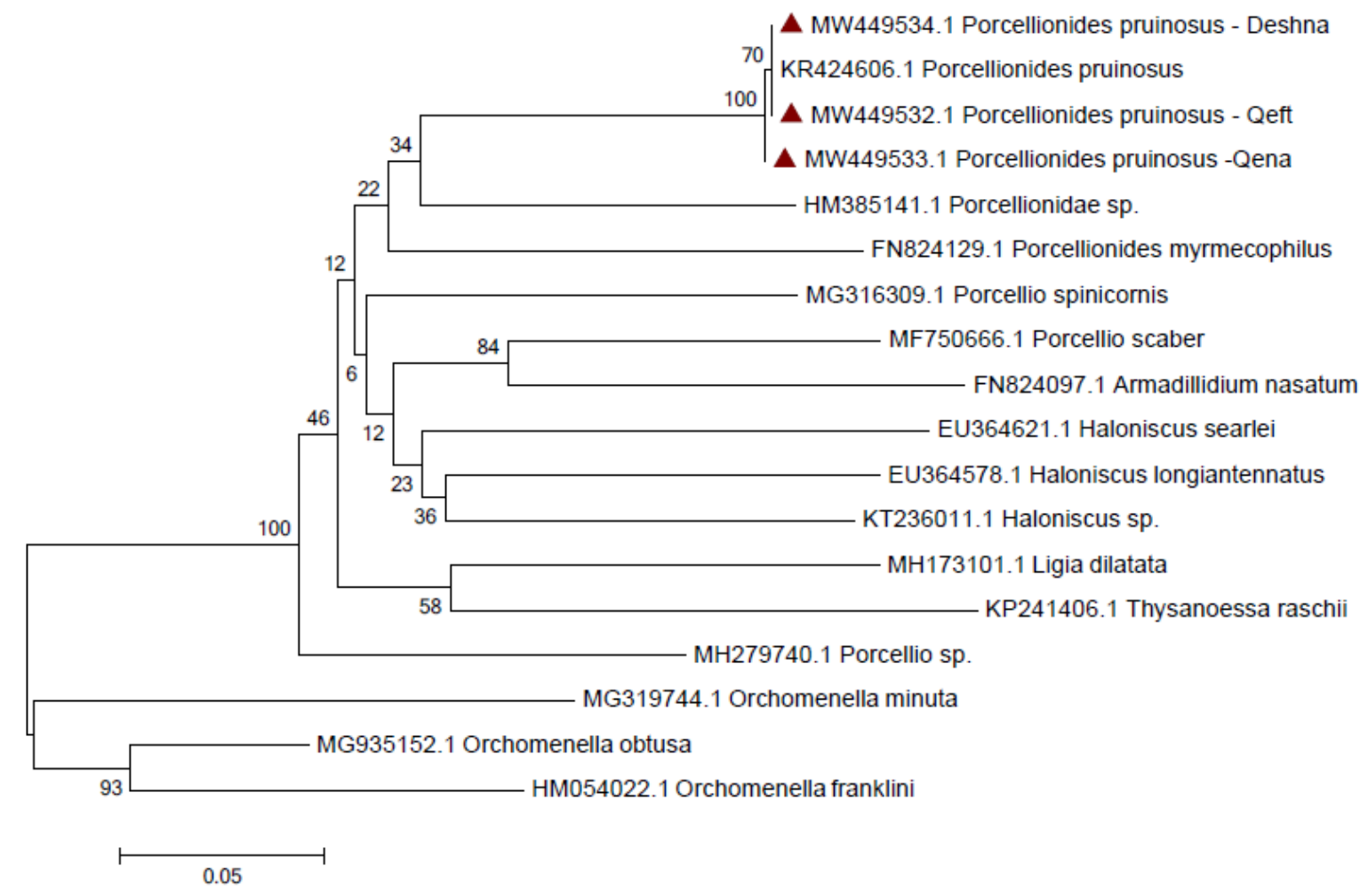

Figure 4: Phylogenetic tree using the minimum evolution method among three Porcellionides pruinosus populations based on mitochondrial cytochrome oxidase subunit 1 (CO1) gene. 
Table 5: Accession numbers, nucleotide frequencies, and their averages mitochondrial cytochrome oxidase subunit 1 (CO1) gene in three Porcellio laevis populations.

\begin{tabular}{|c|c|c|c|c|c|c|c|c|}
\hline \multirow{2}{*}{ Population } & \multirow{2}{*}{$\begin{array}{l}\text { Accession } \\
\text { Number }\end{array}$} & \multirow{2}{*}{$\begin{array}{l}\text { Base Pair } \\
\text { Length }\end{array}$} & \multicolumn{4}{|c|}{ Nucleotide (\%) } & \multirow{2}{*}{$\begin{array}{c}\mathrm{A}+\mathrm{T} \\
\text { Content }(\%)\end{array}$} & \multirow{2}{*}{$\begin{array}{c}\text { Pyrimidines }(\mathrm{C}+\mathrm{T}) \\
\text { Content }(\%)\end{array}$} \\
\hline & & & A & $\mathrm{T}$ & $\mathrm{C}$ & G & & \\
\hline Deshna & MW449535.1 & 646.0 & 26.2 & 36.8 & 17.0 & 20.0 & 63 & 53.8 \\
\hline Qeft & MW449536.1 & 649.0 & 25.7 & 36.9 & 16.0 & 21.4 & 62.6 & 52.9 \\
\hline Hurghada & MW449537.1 & 660.0 & 25.3 & 39.1 & 14.4 & 21.2 & 64.4 & 53.5 \\
\hline Average $\%$ & - & & 25.7 & 37.6 & 15.8 & 20.9 & 63.3 & 53.4 \\
\hline
\end{tabular}
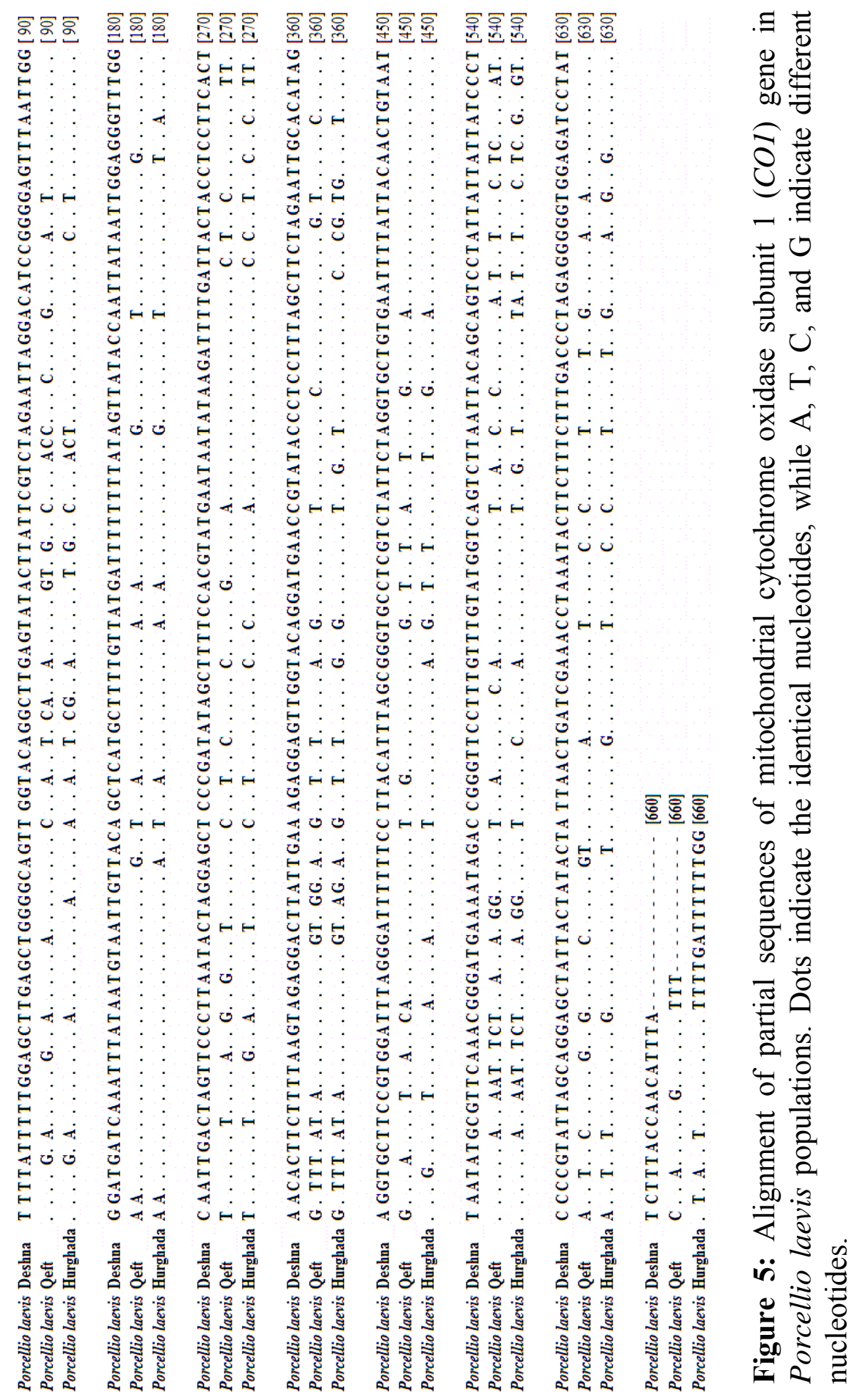
The sequences of CO1 in the three Porcellio laevis populations were subjected to BLAST/N at (NCBI) and revealed 20 related species, from order Isopoda; representing four species (Porcellio laevis, Porcellio imbutus, Porcellio sp., and Porcellionidae sp.) of family Porcellionidae, four species (Idotea resecata, Idotea urotoma, Idoteidae sp., and Synisoma capito) of family Idoteidae, four species (Mongoloniscus sinensis, Mongoloniscus koreanus, Trachelipus rathkii, and Trachelipus kytherensis) of family Trachelipodidae, two species (Halophiloscia couchii and Halophiloscia hirsuta) of family Halophilosciidae, two species (Haloniscus longiantennatus and Haloniscus sp.) of family Scyphacidae, and one species (Amphisopus lintoni, Ligia perkinsi, Sphaeromatidae sp., and Tylos sp.) from each of the families Amphisopidae, Ligiidae, Sphaeromatidae, and Tylidae, respectively; in addition to the outgroup species (Orchomenella obtusa, Orchomenella cavimanus, and Orchomenella rotundifrons) of family Lysianassidae, order Amphipoda (Table 3).

Pairwise genetic distances among the understudied populations of Porcellio laevis ranged from 0.017 to 0.033 . The most related populations were in Qeft and Hurghada, where the genetic distance was 0.017 . The Pairwise genetic distances among the understudied Porcellio laevis populations and the related species of order Isopoda ranged from 0.002 to 0.037 . Overall, the mean distance value was $0.251 \%$. Among all 20 related isopod species, the closely genetic species to the understudied populations was Porcellio laevis (HM385125.1), while Amphisopus lintoni (JX519295.1) was the distantly species (Table 6).

To carry out the phylogenetic tree analysis using CO1 sequencing, the three Porcellio laevis populations were submitted to the analysis together with the 20 related isopod species sequences and the out-group species from GenBank/NCBI (previously mentioned in Table 3). For more illustrative phylogenetic relations, we used more than one phylogenetic method (ML, NJ, and ME) based on $\mathrm{CO} 1$ gene. The methods showed nearly the same relations with some differences in support values and revealed 4 main features: (1) Species of the out-group formed a separate cluster. (2) The understudied Porcellio laevis of Qeft population formed a sister clade with Porcellio laevis (HM385125.1). (3) Both Porcellio laevis populations of Deshna and Hurghada formed a separate clade. (4) Porcellio laevis populations of Deshna formed a separate clade far from the rest of Porcellio laevis populations (Figures 6-8).

\section{DISCUSSION}

CO1 is the core gene utilized by DNA barcoding studies and plays an important role to facilitate both the diagnosing of known species, as well as the discovery of new species ${ }^{[27]}$. Several studies illustrated the effects of DNA barcodes in identification of species ${ }^{[36-39]}$. The present study revealed that the partial sequencing of CO1 among populations of the two isopod species "Porcellionides pruinosus and Porcellio laevis" ranged from $646 \mathrm{bp}$ to $660 \mathrm{bp}$. This concurs with many studies that used CO1 in invertebrates ${ }^{[29,41-43]}$. Wetzer ${ }^{[40]}$ reported that isopod mitochondrial DNA shows a high ratio of $\mathrm{A}+\mathrm{T}$ in two ribosomal genes (12S rRNA and 16S rRNA). In addition, the third codon position of mitochondrial COI exhibits a high proportion of $\mathrm{A}+\mathrm{T}$ content. The average content of $\mathrm{A}+\mathrm{T}$ in Porcellionides pruinosus and Porcellio laevis in the present investigation was $63.8 \%$ and $63.3 \%$, respectively. The contents of $\mathrm{A}+\mathrm{T}$ were higher than $\mathrm{C}+\mathrm{G}$ contents in all populations; these agree with Chen et al. ${ }^{[42]}$ who found that the average composition of $\mathrm{A}+\mathrm{T}$ was $63.5 \%$ in 9 genera of Scelimeninae using $\mathrm{CO} 1$ gene.

The global species Porcellionides pruinosus (Brandt, 1833) display geographical diversity of its morphological characteristics and its reproduction pattern. 


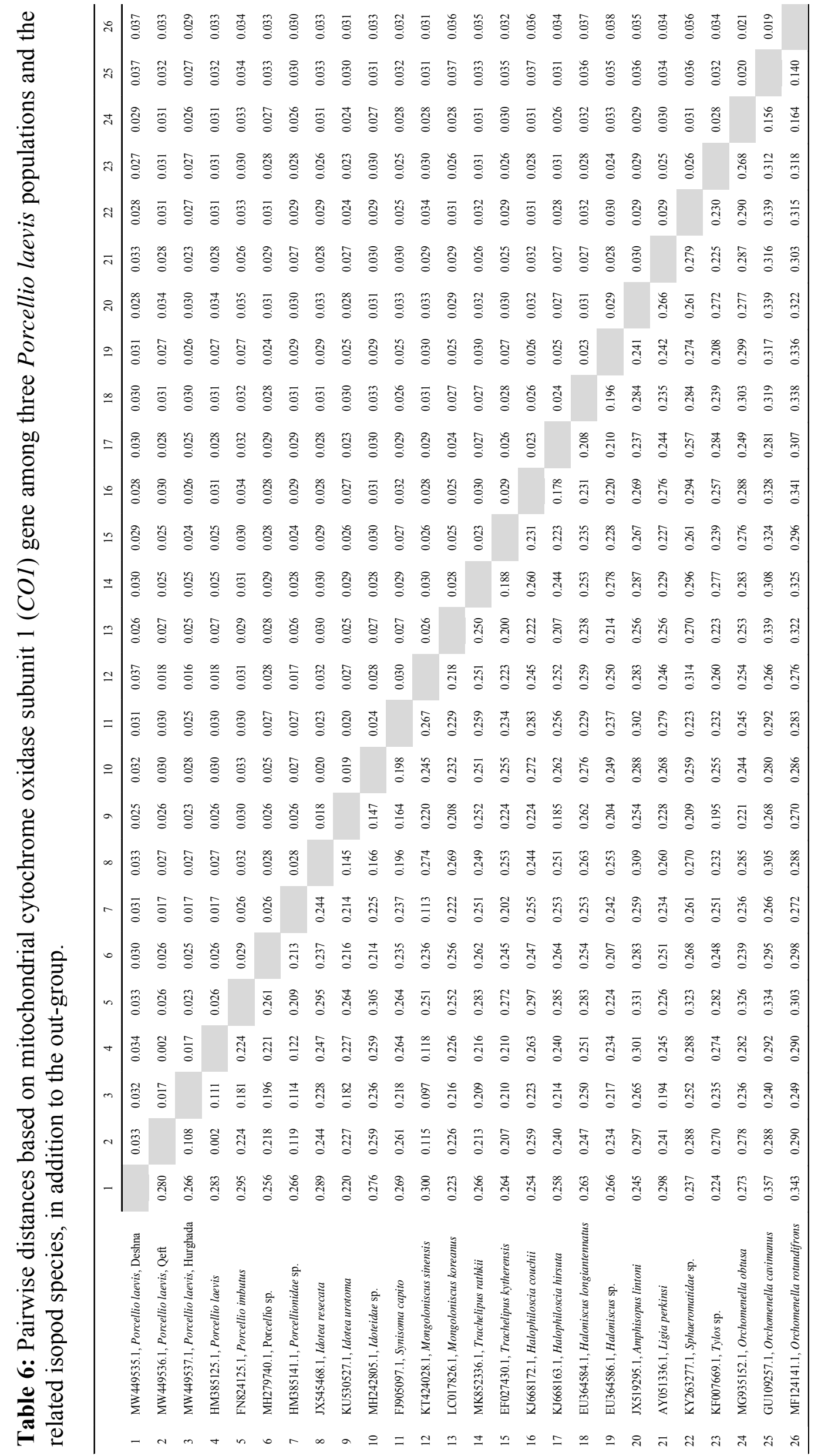




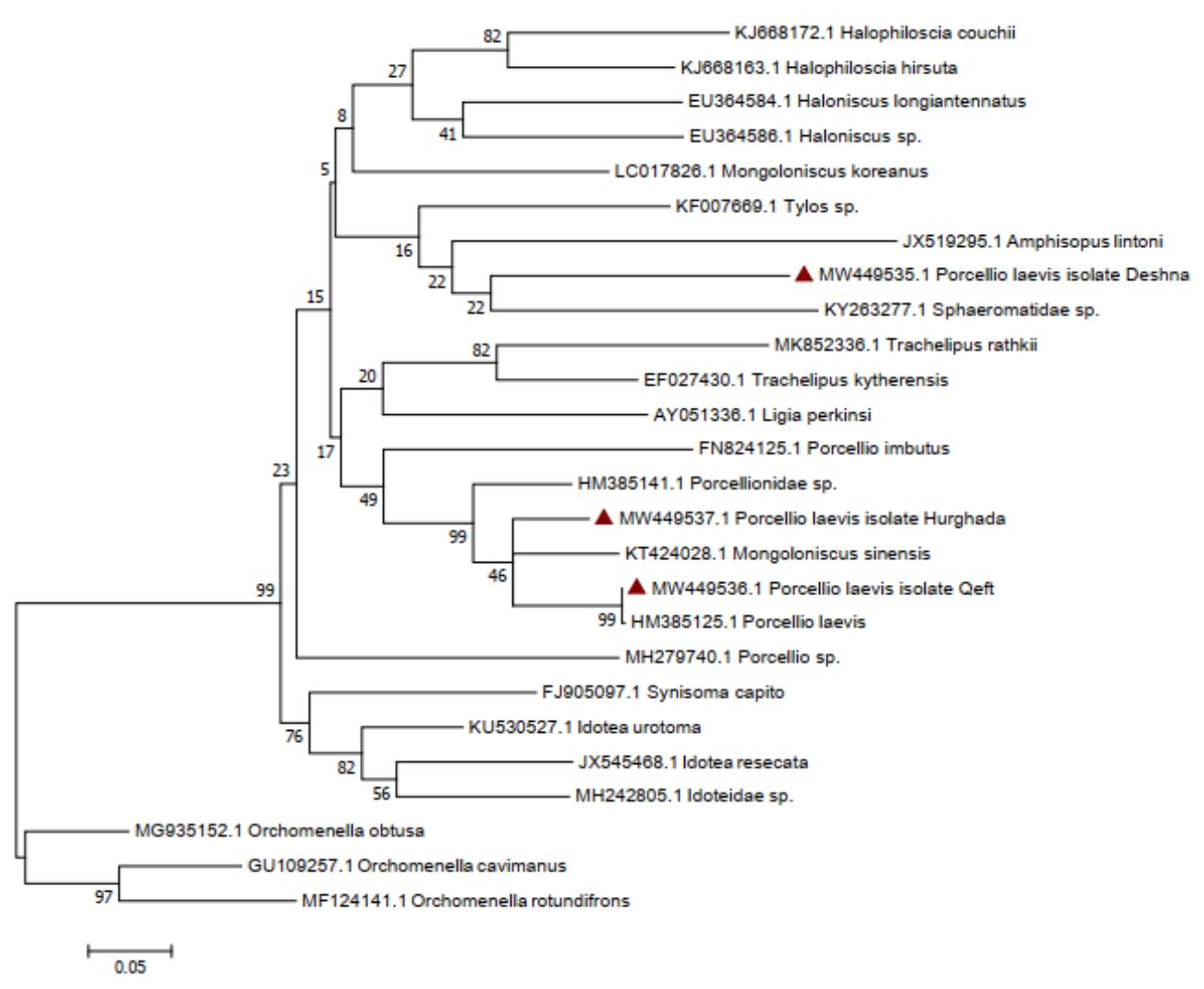

Figure 6: Phylogenetic tree using the maximum likelihood method among three Porcellio laevis populations based on mitochondrial cytochrome oxidase subunit 1 (CO1) gene.

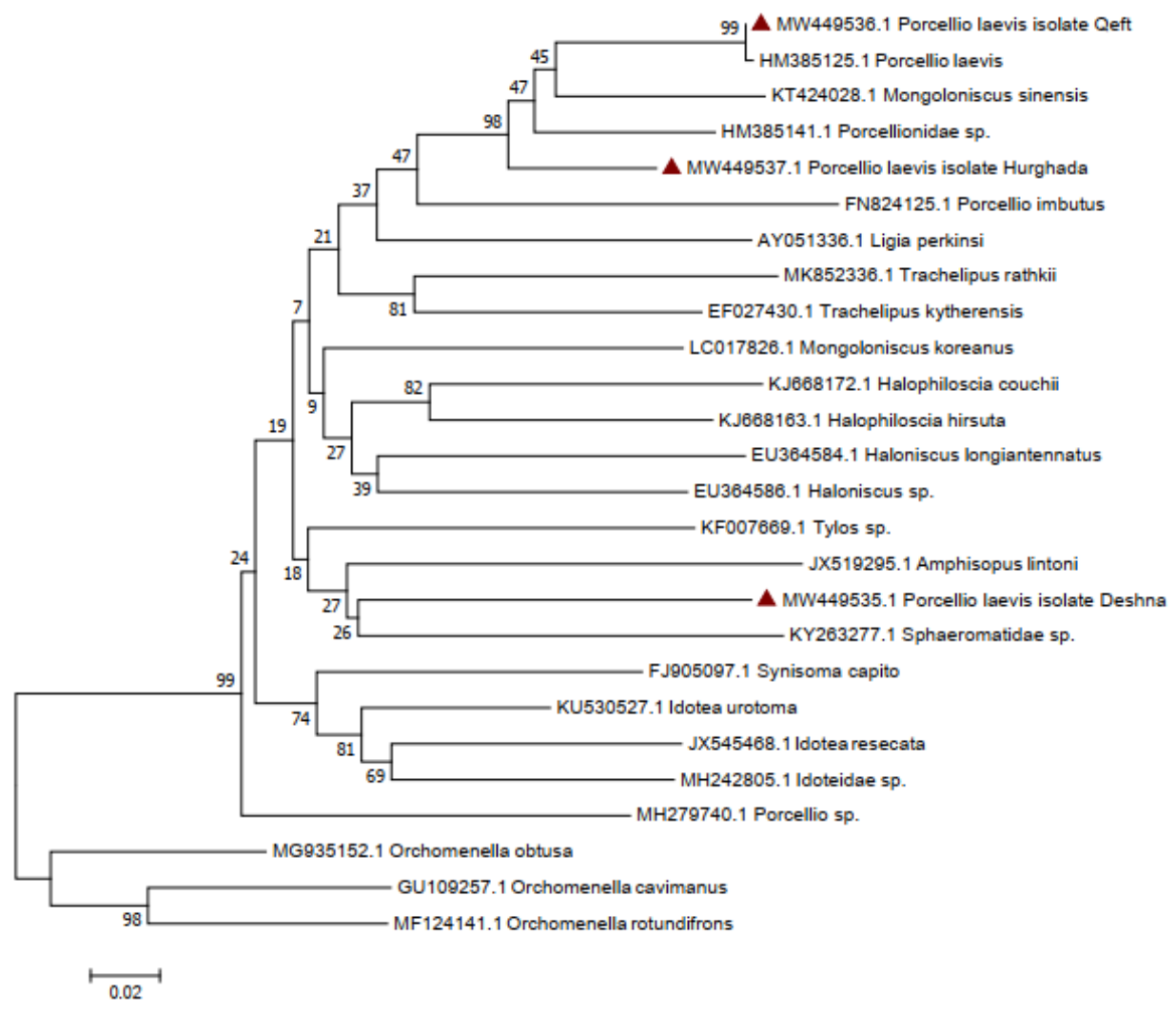

Figure 7: Phylogenetic tree using the neighbor joining method among three Porcellio laevis populations based on mitochondrial cytochrome oxidase subunit 1 (CO1) gene. 


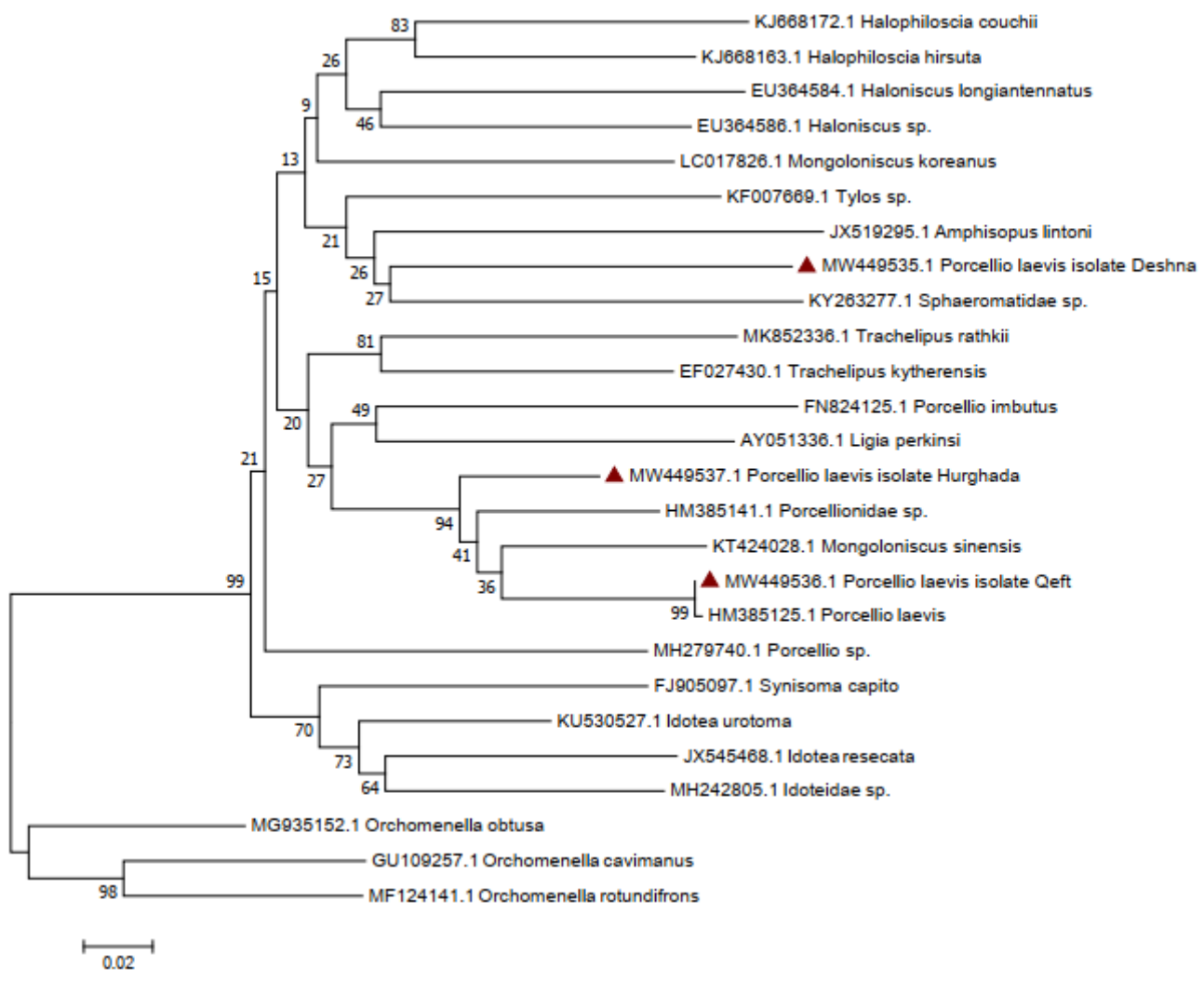

Figure 8: Phylogenetic tree using the minimum evolution method among three Porcellio laevis populations based on mitochondrial cytochrome oxidase subunit 1 (CO1) gene.

In addition, it has a dialectical taxonomic history and wide ecological plasticity ${ }^{[14]}$. Pairwise genetic distances among Porcellionides pruinosus populations, in our present study, ranged from 0.000 to 0.002 . This closely genetic relation was consistent with the findings of Delhoumi et $a .^{[14]}$, who reported that the lowest genetic distances among populations of Porcellionides pruinosus in Tunisia, was found among Sbiba, Elfeija, Monastir, Chebba, and Sned.

The study of Rigaud et al. ${ }^{[44]}$ on Armadillidium vulgare populations in western France reported that although some sites being more than $300 \mathrm{~km}$ apart, but there was not any genetic isolation by distance. Also, Lee et al. ${ }^{[15]}$ found no COI genetic diversity among Spherillo grossus populations at Batemans Bay, Burleigh Heads, Woy Woy, Wollongong, and Urunga regions in Australia, although more than one specimen being collected and sequenced at each site. Likewise, Chen et al. ${ }^{[42]}$ showed a close genetic distance (0.004) of the two geographical populations of Paragavialidium sichuanensis in Zhougongshan and Bifengxia. A phylogeographic study on Porcellio scaber (Latreille, 1804) in Europe was found that human passive dispersal has been a significant factor in shaping genetic variation across the continent ${ }^{[45]}$.

In the present study, pairwise genetic distances among Porcellio laevis populations based on mitochondrial CO1 ranged from 0.017 to 0.033 , and the highest level of the genetic variation was in accordance with several studies on terrestrial isopods. Cooper et al. ${ }^{[46]}$ using CO1 sequences in genus Haloniscus (Chilton, 1919), cave-dwelling oniscid found in Western Australia, revealed that p-distances of up to $10.7 \%$ were found between sites. Hurtado et al. ${ }^{[17]}$ during their 
study on the rocky-shore oniscid species "Ligia occidentalis (Dana, 1853)" found that CO1 p-distances were up to $26 \%$ between populations in the Gulf of California. In the same species ${ }^{[18]}$, a pairwise distance was of up to $26.7 \%$ between population, and of up to $25 \%$ between populations was found ${ }^{[47]}$. In all these cases, the high ratios of genetic variation were considered as an indicator of specieslevel divergences between lineages ${ }^{[15]}$.

The present findings showed that, the final alignments in Porcellio laevis consisted of $660 \mathrm{bp}$; out of them 497, 152, and 1 were conserved sites, variable sites, and parsimony informative sites, respectively. Dimitriou et al. ${ }^{[29]}$ used $C O 1$ in five Porcellionidae genera and reported that the alignment length, conserved sites, variable sites, and Parsimony informative sites were 655, 214, 434, and $303 \mathrm{bp}$, respectively. The present phylogenetic tree analysis based on mitochondrial CO1 in Porcellio laevis populations revealed that Deshna population formed a separate clade far from the Qeft and Hurghada populations. Thus, the Porcellio laevis populations need more investigations, as it seems to be polyphyletic comparing with Porcellionides pruinosus populations. Brix et al. ${ }^{[48]}$ declared, despite the uniform morphology, genetic divergence refers to the presence of overlooked or cryptic species in isopods. In addition to that, Dimitriou et al. ${ }^{[29]}$ proclaim the extremely high genetic distances that reached up to 50.3 in mitochondrial DNA and 44.2 in nucleus DNA, which supported the vast divergence among taxa within Porcellionidae. Also, the genus Porcellio needs to be revised, as it seems to be polyphyletic, including at least two separate groups.

In conclusion, the present study investigated the phylogeographic population and genetic diversity of two terrestrial isopods Porcellionides pruinosus and Porcellio laevis based on CO1 sequence. The results of CO1 sequences illustrated closely genetic relationship between Qeft and Deshna Porcellionides pruinosus populations, while the most related Porcellio laevis populations were Qeft and Hurghada. The CO1 Sequence seems to be useful in exposing differences in Porcellionides pruinosus and Porcellio laevis specimens from different localities in Egypt, it is clear that there is an environment effect on the genetic structure

\section{FUNDING SOURCE DISCLOSURE}

This research received no specific grant from any funding agency in the public, commercial, or not-for-profit sectors.

\section{CONFLICT OF INTEREST}

The authors have no potential financial conflict of interest.

\section{REFERENCES}

[1] Paoletti, M. G. and Hassall, M. (1999). Woodlice (Isopoda: Oniscidea): their potential for assessing sustainability and use as bioindicators. Agric Ecosyst Environ, 74: 157-165.

[2] Souty-Grosset, C.; Badenhausser, I.; Reynolds, J. D. et al. (2005). Investigations on the potential of woodlice as bioindicators of grassland habitat quality. Eur J Soil Biol, 41(3): 109-116.

[3] Amari, T.; Zaabar, W.; Semmar, N. et al. (2019). Porcellio laevis (Crustacea, Isopoda) from soil detritivore to vegetable crop pest: case study of the melon (Cucumis melo L., Cucurbitaceae). Vie et Milieu/Life and Environment, 69(2-3): 123-135.

[4] Achouri, M. S.; Bouslama, M. F.; Hamaïed, S. et al. (2012). Genetic differentiation and gene flow of Porcellionides pruinosus (Crustacea: Isopoda: Oniscidea) in Tunisia. Journal of Natural History, 46(33-34): 2019-2031.

[5] Schmalfuss, H. (2003). World Catalog of Terrestrial Isopods (Isopoda: Oniscidea). Stuttgarter Beiträge zur Naturkunde, Serie A (Biologie), Number 654. Staatliches Museum für 
Naturkunde, Stuttgart, Germany.

[6] Paris, O. H. (1965). Vagility of $\mathrm{P}^{32}$ labeled isopods in Grassland. Ecology, 46(5): 635-648.

[7] Sorensen, E. M. B. and Burkett, R. D. (1977). A population study of the isopod, Armadillidium vulgare, in northeastern Texas. Southwest Nat, 22(3): 375-387.

[8] Sfenthourakis, S. and Hornung, E. (2018). Isopod distribution and climate change. ZooKeys, 801: 25-61.

[9] Sfenthourakis, S. and Taiti, S. (2015). Patterns of taxonomic diversity among terrestrial isopods. ZooKeys, 515: 1325.

[10] Schmidt, C. (2003). Contribution to the phylogenetic system of the Crinocheta (Crustacea, Isopoda). Part 2. (Oniscoidea to Armadillidiidae). Zoosyst Evol, 79: 3-179.

[11] Medini-Bouaziz, L.; El Gtari, M.; Hamaied, S. et al. (2017). Population dynamics and reproductive aspects of Porcellio albinus (Isopoda, Oniscidea) of Zarat (Gabes, Tunisia). Invertebr Reprod Dev, 61: 18-26.

[12] Garthwaite, R. and Sassaman, C. (1985). Porcellionides floria, new species, from North America; provinciality in the cosmopolitan isopod Porcellionides pruinosus (Brandt). J Crustac Biol, 5(3): 539-555.

[13] Michel-Salzat, A.; Cordaux, R. and Bouchon, D. (2001). Wolbachia diversity in the Porcellionides pruinosus complex of species (Crustacea: Oniscidea): evidence for host-dependent patterns of infection. Heredity, 87(4): 428-434.

[14] Delhoumi, M.; Zaabar, W.; Bouslama, M. F. et al. (2019). High level of genetic variation in mitochondrial 16S rDNA among populations of Porcellionides pruinosus (Brandt, 1833) (Crustacea: Isopoda: Oniscidea) in Tunisia. Eur Zool J, 86: 1-8.

[15] Lee, T. R. C.; Ho, S. Y. W.; Wilson, G. D. F. et al. (2014). Phylogeography and diversity of the terrestrial isopod Spherillo grossus (Oniscidea: Armadillidae) on the Australian East Coast. Zool J Linn Soc, 170(2): 297-309.

[16] Jung, J.; Eo, H.-S.; Rho, H. S. et al. (2008). Two genetic lineages of sea slaters, Ligia (Crustacea: Isopoda) in South Korea: a population genetic approach. Mol Cells, 25(4): 523-530.

[17] Hurtado, L. A.; Mateos, M. and Santamaria, C. A. (2010). Phylogeography of supralittoral rocky intertidal Ligia isopods in the Pacific region from central California to central Mexico. PLoS ONE 5(7): e11633 (DOI:10.1371/ journal.pone. 0011633).

[18] Markow, T. A. and Pfeiler, E. (2010). Mitochondrial DNA evidence for deep genetic divergences in allopatric populations of the rocky intertidal isopod Ligia occidentalis from the eastern Pacific. Mol Phylogenet Evol, 56: 468-473.

[19] Rangoju, P. K.; Kumar, S.; Kolte, A. P. et al (2007). Assessment of genetic variability among rabbit breeds by random amplified polymorphic DNA (RAPD)-PCR. World Rabbit Sci, 15: 3-8.

[20] Oseni, S. O. and Oke, O. O. (2012). Morphological and quantitative characteristics of a composite rabbit population in backyard systems in southwestern Nigeria. Proceedings $10^{\text {th }}$ World Rabbit Congress, Sharm El- Sheikh, Egypt, 223-227.

[21] Abdel-Kafy, E. M.; Ghaly, I. S.; Ben Larbi, M. et al. (2016). Genetic diversity and phenotype characterization of native rabbit in Middle-Egypt. Journal of new sciences, Agriculture and Biotechnology, IABC(16): 1312-1320.

[22] Moritz, C.; Dowling, T. E. and Brown, W. M. (1987). Evolution of animal mitochondrial DNA: relevance for population biology and systematics. Annu Rev Ecol Syst, 18: 269-292.

[23] Sotelo, C. G.; Piñeiro, C.; Gallardo, 
J. M. et al. (1993). Fish species identification in seafood products. Trends Food Sci Technol, 4(12): 395401.

[24] Unseld, M.; Beyermann, B.; Brandt, P. et al. (1995). Identification of the species origin of highly processed meat products by mitochondrial DNA sequences. PCR Methods Appl, 4(4): 241-243.

[25] Galtier, N.; Nabholz, B.; Glémin, S. et al. (2009). Mitochondrial DNA as a marker of molecular diversity: a reappraisal. Mol Ecol, 18(22): 45414550.

[26] Tiwary, C.; Badhul Haq, M. A.; Vaitheeswari, S. et al. (2016). DNA barcoding and intra species analysis of the ember parrot fish Scarus rubroviolaceus using mtCO1. IRA-Int J Appl Sci, 5(2): 91-109.

[27] Hebert, P. D. N.; Ratnasingham, S. and deWaard, J. R. (2003). Barcoding animal life: cytochrome c oxidase subunit 1 divergences among closely related species. Proc Biol Sci, 270(Suppl. 1): S96-S99.

[28] Kaleshkumar, K.; Rajaram, R.; Vinothkumar, S. et al. (2015). DNA barcoding of selected species of pufferfishes (Order: Tetraodontiformes) of Puducherry coastal waters along south-east coast of India. Indian J Fish, 62(2): 98-103.

[29] Dimitriou, A. C.; Taiti, S.; Schmalfuss, H. et al. (2018). A molecular phylogeny of Porcellionidae (Isopoda, Oniscidea) reveals inconsistencies with present taxonomy. ZooKeys, 801: 163-176.

[30] Shultz, J. W. (2018). A guide to the identification of the terrestrial isopoda of Maryland, U.S.A. (Crustacea). ZooKeys, 801: 207-228.

[31] Folmer, O.; Black, M.; Hoeh, W. et al. (1994). DNA primers for amplification of mitochondrial cytochrome c oxidase subunit I from diverse metazoan invertebrates. Mol Mar Biol
Biotechnol, 3(5): 294-299.

[32] Edgar, R. C. (2004). MUSCLE: multiple sequence alignment with high accuracy and high throughput. Nucleic Acids Res, 32(5): 1792-1797.

[33] Kumar, S.; Stecher, G. and Tamura, K. (2016). MEGA7: Molecular evolutionary genetics analysis version 7.0 for bigger datasets. Mol Biol Evol, 33(7): 1870-1874.

[34] Felsenstein, J. (1985). Confidence limits on phylogenies: an approach using the bootstrap. Evolution, 39(4): 783-791.

[35] Kimura, M. (1980). A simple method for estimating evolutionary rates of base substitutions through comparative studies of nucleotide sequences. J Mol Evol, 16(2): 111-120.

[36] Hebert, P. D. N.; Penton, E. H.; Burns, J. M. et al. (2004). Ten species in one: DNA barcoding reveals cryptic species in the neotropical skipper butterfly Astraptes fulgerator. Proc Natl Acad Sci U S A, 101(41): 14812-14817.

[37] Barrett, R. D. H. and Hebert, P. D. N. (2005). Identifying spiders through DNA barcodes. Can J Zool, 83(3): 481-491.

[38] Smith, M. A.; Woodley, N. E.; Janzen, D. H. et al. (2006). DNA barcodes reveal cryptic host-specificity within the presumed polyphagous members of a genus of parasitoid flies (Diptera: Tachinidae). Proc Natl Acad Sci U S A, 103(10): 3657-3662.

[39] Seifert, K. A.; Samson, R. A.; deWaard, J. R. et al. (2007). Prospects for fungus identification using CO1 DNA barcodes, with Penicillium as a test case. Proc Natl Acad Sci U S A, 104(10): 3901-3906.

[40] Wetzer, R. (2001). Hierarchical analysis of mtDNA variation and the use of mtDNA for isopod (Crustacea: Peracarida: Isopoda) systematics. Contrib Zool, 70: 23-39.

[41] Klossa-Kilia, E.; Kilias, G.; Tryfonopoulos, G. et al. (2006). Molecular phylogeny of the Greek 
populations of the genus Ligidium (Isopoda, Oniscidea) using three mtDNA gene segments. Zool Scr, 35(5): 459-472.

[42] Chen, Y. Z.; Deng, W. A.; Wang, J. M. et al. (2018). Phylogenetic relationships of Scelimeninae genera (Orthoptera: Tetrigoidea) based on COI, 16S rRNA and 18S rRNA gene sequences. Zootaxa, 4482(2): 392-400.

[43] Karasawa, S. and Goto, K. (2014). Burmoniscus kitadaitoensis nunomura, 2009 (Crustacea, Isopoda, Oniscidea) from southern Japan, a junior synonym of B. meeusei (Holthuis, 1947). ZooKeys, 386: 21-28.

[44] Rigaud, T.; Bouchon, D.; SoutyGrosset, C. et al. (1999). Mitochondrial DNA polymorphism, sex ratio distorters and population genetics in the isopod Armadillidium vulgare. Genetics, 152(4): 1669-1677.

[45] Wang, M. and Schreiber, A. (2009). Population genetics of the woodlouse
Porcellio scaber Latr. (Isopoda: Oniscoidea) in central Europe: passive dispersal and postglacial range expansion. Can J Zool, 77(9): 13371347.

[46] Cooper, S. J. B.; Saint, K. M.; Taiti, S. et al. (2008). Subterranean archipelago: mitochondrial DNA phylogeography of stygobitic isopods (Oniscidea: Haloniscus) from the Yilgarn region of Western Australia. Invertebr Syst, 22: 195-203.

[47] Eberl, R.; Mateos, M.; Grosberg, R. K. et al. (2013). Phylogeography of the supralittoral isopod Ligia occidentalis around the Point Conception marine biogeographic boundary. J Biogeogr, 40(12): 2361-2372.

[48] Brix, S.; Svavarsson, J. and Leese, F. (2014). A multi-gene analysis reveals multiple highly divergent lineages of the isopod Chelator insignis (Hansen, 1916) south of Iceland. Pol Polar Res, 35(2): 225-242.

\section{How to cite this article:}

Allam, M.; Fangary, H. M. and Mar'ie, Z. A. (2021). Phylogeographic and genetic diversity of Porcellionides pruinosus and Porcellio laevis by using the mitochondrial cytochrome c oxidase subunit 1 sequence. Egyptian Journal of Zoology, 76: 12-29 (DOI: 10.21608/ejz.2021.73095.1054). 


\section{"Porcellionides pruinosus" العلاقات الجغرافية والتنوع الوراثي لكل من

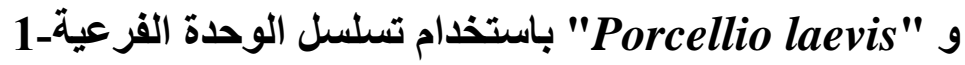 للسيتوكروم سي أوكسيديز الميتوكوندري بليكل \\ محمد علام¹، هبة محمد فنجري1، زينب عبد الخالق مرعي21،

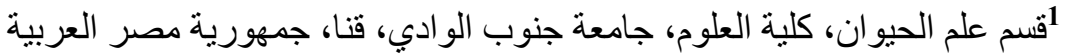

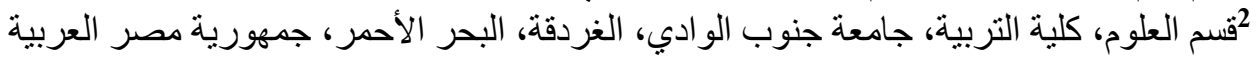

تُعتبر الفصيلة "Porcellionidae" الأكثر ثراء بالأنواع والموزعة على نطاق واسع من بين فصائل تحت رنبة

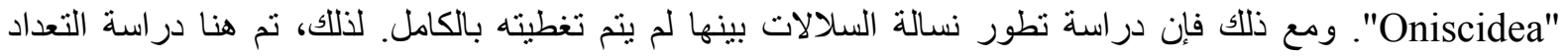
الجغر افي و التنوع الجيني على نوعين من منماثلاث الأرجل الأرضية المنتشرة عالميًا

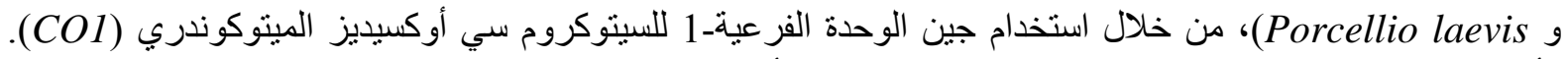

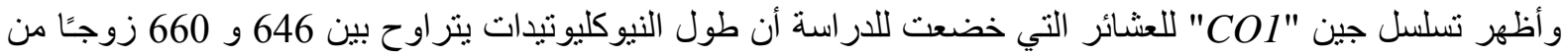
القواعد. وبلغ متوسط محتوى قواعد النيوكليوتيدات من الأدنين + النايمين في "Porcellionides pruinosus" و Porcellio laevis"

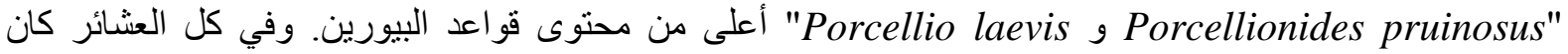

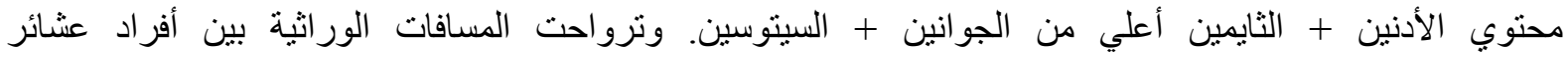
Porcellionides pruinosus"

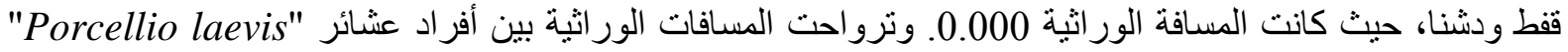

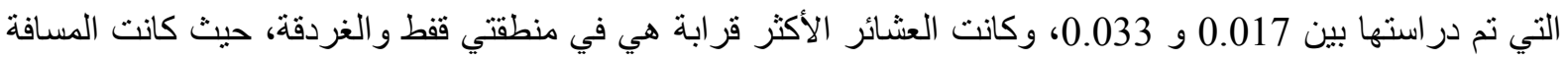

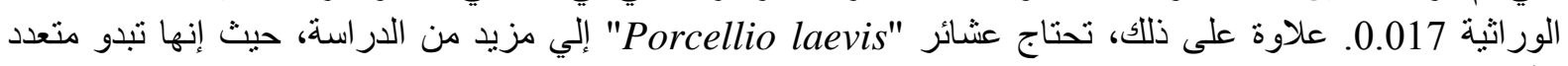

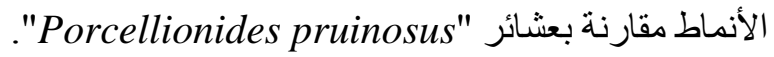

